\title{
An unusual use of Simpson forceps
}

\author{
Jack Cohen BSc BA MD CM \\ St Mary's and Jewish General Hospitals, Montreal, Quebec
}

\section{J Cohen. An unusual use of Simpson forceps. Can J Plast Surg 2000;8(6):225-226.}

An unusual use of Simpson forceps is presented. A woman in her 40s who had undergone subglandular augmentation mammoplasty with a pair of $120 \mathrm{cc}$ silicone prostheses 20 years earlier presented to the medical office. For several months, she had been experiencing tenderness and pain in her breasts. After examination, an operation to replace the prostheses was performed under general anesthesia. Upon opening the right breast, it was found that the capsule around the prosthesis had completely calcified, and, could not be incised with a scalpel. By using Simpson forceps, the capsule was retracted inferiorly, and the dissection was completed without nicking or lacerating the breast skin.

Key Words: Capsule; Silicone prostheses; Simpson forceps

\section{Utilisation inhabituelle des forceps de Simpson}

RÉSUMÉ : On présente ici une utilisation inhabituelle des forceps de Simpson. Une femme dans la quarantaine a subi une mammoplastie d'augmentation sous-glandulaire par prothèses à la silicone de $120 \mathrm{cc}$ il y a 20 ans et se présente au cabinet médical. Depuis plusieurs mois, elle présente une sensibilité et une douleur aux seins. Après examen, on opte pour une intervention en vue de remplacer les prothèses sous anesthésie générale. À l'incision du sein droit, on découvre que la capsule qui entoure la prothèse s'est complètement calcifiée, au point d'être impossible à inciser au scalpel. À l'aide de forceps de Simpson, la capsule a été rétractée vers le bas et la dissection a pu être complétée, sans rétrécissement ou lacération de la peau du sein.

$\mathrm{J}^{\mathrm{s}}$ ames Young Simpson (1811 to 1870) was one of the most eminent obstetricians of Britain in his day. Among his accomplishments were the introduction of anesthesia in obstetrics, the invention of the uterine sound and the development of obstetrics forceps. Simpson forceps (Sklar Instruments, USA) are still being used in obstetrics (1). An unusual use of these forceps is presented.

\section{CASE PRESENTATION}

A woman in her 40s who had undergone subglandular augmentation mammoplasty with a pair of $120 \mathrm{cc}$ silicone prostheses 20 years earlier presented to the author's office. For several months, she had been experiencing tenderness and pain in her breasts. Examination revealed a Grade III Baker's capsular contracture with tenderness of the breasts. Mammography did not reveal evidence of a rupture of the prosthe- ses or any other abnormalities. Because the patient wanted the silicone prostheses replaced, other methods to detect a rupture of the prostheses were not pursued.

The operation to replace the prostheses was performed under general anesthesia. Upon opening the right breast through the previous inframammary incision, it was found that the capsule around the prosthesis had completely calcified. It could not be incised with a scalpel. The capsule was very adherent to the breast tissue, but a slow, careful dissection allowed it to be removed in toto without buttonholing the skin. The left breast prosthesis was also surrounded by a solidly calcified capsule. When the inferior half of the dissection was performed, the capsule was found to be very adherent to the thin layer of superior breast tissue. Not enough manual traction could be applied to dissect the capsule without presenting the possibility of cutting through the skin. A heavy

Correspondence: Dr Jack Cohen, St Mary's and Jewish General Hospitals, 5885 Cote des Neiges Road, Suite 600, Montreal, Quebec H3S 2T2.

Telephone 514-733-1472, fax 514-733-4857, e-mail jackruth@securenet.net 
Kocher (Sklar Instruments, USA) or a similar instrument would have probably cracked the prosthetic capsular 'shell' and prosthesis, further complicating the dissection by the leakage of sticky silicone.

At this stage, one of the nurses suggested using Simpson forceps. Because the author's hospital has a very active obstetrical service, there is always a sterile pair of forceps in the operating room area. By using the forceps, it was possible to retract the capsule inferiorly, allowing the dissection to be completed without nicking or lacerating the breast skin. The operation was quickly completed. As is often the case in obstetrics, the Simpson forceps saved the day.

\section{REFERENCES}

1. Simpson, Sir James Young, 1st Baronet. Encyclopedia Brittanica Online. $<$ http: $/ /$ members.eb.com.bol/topic?Eu=69636\&sctn=1> (Version current at April 25, 1999). 